\title{
Kevin O'Brien and Li Lianjiang, Rightful Resistance in Rural China
}

Chloé Froissart

\section{(2) OpenEdition}

\section{Journals}

Édition électronique

URL : http://journals.openedition.org/chinaperspectives/2723

DOI : 10.4000/chinaperspectives. 2723

ISSN : 1996-4617

Éditeur

Centre d'étude français sur la Chine contemporaine

\section{Édition imprimée}

Date de publication : 15 décembre 2007

ISSN : 2070-3449

\section{Référence électronique}

Chloé Froissart, "Kevin O'Brien and Li Lianjiang, Rightful Resistance in Rural China », China Perspectives [En ligne], 2007/4 | 2007, mis en ligne le 09 avril 2008, consulté le 21 septembre 2020. URL : http:// journals.openedition.org/chinaperspectives/2723; DOI : https://doi.org/10.4000/chinaperspectives. 2723

Ce document a été généré automatiquement le 21 septembre 2020.

(C) All rights reserved 


\title{
Kevin O'Brien and Li Lianjiang, Rightful Resistance in Rural China
}

\author{
Chloé Froissart
}

1 Rightful Resistance in Rural China is a good example of the heuristic character of the inductive method in political sociology, that is to say, the manner in which a new social reality leads to an evolution in the theoretical framework of a discipline. The book is the product of an impressive 10 years of field work that began in 1994 and ranges from extensive quantitative studies conducted in partnership with Chinese universities to hundreds of semi-direct interviews with farmers and officials. The authors have also tapped greatly diverse primary sources, from government reports to villagers' complaints, press reports, and Chinese researchers' studies. But the work is presented mainly as an effort in conceptualisation and theorisation of a type of contentious action that can be defined in terms of neither institutional participation nor social movements, nor even of "everyday forms of resistance" theorised by James Scott, while presenting many characteristics of each of these forms of action. So what is it about? It is a fight to compel the authorities to narrow the gap between what they say and what they do in a context where rights that are recognized - more or less formally - are not guaranteed ${ }^{1}$.

2 The concept of "rightful resistance" demolishes a postulate that has long prevailed among theories of collective action, which is that there are two distinct types: conventional-institutional actions and collective non-institutional ones, the latter uninformed by established social norms. The specificity of this type of resistance is that it strains the limits of institutionalized channels of contention (and cannot thus qualify as either completely institutionalized or non-institutional), combining, for instance, litigation or administrative procedures with political pressure; and that it invokes official values, operating within the framework of these values yet in tension with them. We are thus confronted with an atypical form of resistance that effectively opposes the appropriation of resources and forms of political control deemed illegitimate, but does not question the legitimacy of the authorities as such, and does not fall under the classical scheme of societal opposition to the state; rather, it develops 
vertical alliances that exploit divisions within the state and seeks elite support. Rightful Resistance in Rural China thus belongs to a current in political sociology that since the 1990s has tended to rethink the notion of conflict outside the mere binary state-society or dominant- dominated opposing schemes by showing how the poor and the weak can defend their interests by invoking norms proclaimed by a state that is not seen as monolithic.

3 This brief but dense book (with only six chapters) is remarkable in many respects. It invents and exposes in a highly didactic manner a new concept that will leave a mark in political science. While the preface - a model in the genre - takes account of progress made in analytical steps and retraces the genesis of the concept, the first chapter sets about demonstrating its scientific value using a comparative perspective. The concept of "rightful resistance" is not synonymous with Chinese exception, as it can cover similar collective actions in other times and under other regimes, including Western pluralistic democracies ${ }^{2}$. Thus the book is aimed as much at China hands as at sociologists and political scientists not specialising in the country, especially as it keeps up a constant dialogue with the literature on collective action, making the most of theoretical contributions to the field. The authors succeed in reconciling approaches that have often been - wrongly - deemed divergent, taking as much interest in the origin, development, and means of action as in its consequences, and also taking note of macro and micro-sociological aspects such as the structure of political opportunities and how they are seen by the actors, and the consequences of the action on the system and on individuals.

4 Moreover, the book marks a major contribution towards understanding the dynamics at work in the relationship between state and society in China : it highlights the deep contradictions within the regime and the way in which these are exploited by the people. It demonstrates how this type of resistance leads to systemic developments (legislation is strengthened, local officials are compelled to be more accountable to villagers) and how that in turn affects the forms and content of claims. Taking as much interest in the objective determinants of action as in subjective consequences of its failure or success, the authors carry out a subtle and convincing analysis of the evolution of the repertory of protest during the 10 years of their study. Collective action tends to become more and more direct and autonomous, that is to say, noninstitutionalized: encouraged by growing support within the village community, it prefers protests to petitions, and direct confrontation with opponents to seeking patrons from among the elites. Finally, one of the major merits of the book is its nuanced appreciation of the nature and consequences of this type of protest, stressing that its dynamics also constitute its limits.

5 The protesters in fact seek legitimacy for their action by projecting themselves as ardent defenders of a regime they see as having gone astray, endangered by its local representatives. Because the protesters' identification with the Central authorities serves as the springboard for their action, it cannot lead to radical change in power relations and tends instead to boost the Party's legitimacy. But this form of resistance also opens up a social space, pushing back the boundaries of what is permitted and nurturing debate on values and norms. It attests to the emergence of a more contractual relation between the state and society, that is to say, the evolution of what is expected from the state and in the way law is perceived, but not of the perception of individual rights as inher ent in the human person. The authors thus conclude that this 
form of resistance has more of a sociological than political impact, while also putting forward the hypothesis that the Central authorities could eventually be overtaken by demands that tend to become more radical through a dynamic that is beyond their control.

Meanwhile, the book raises a question: to what extent has this "rightful resistance" become an integral part of the functioning of the Chinese regime, and could that help explain the regime's formidable ability to endure and adapt? The authors show how this resistance finds its origin in the convergence (part real, part assumed) of the interests of protesters and Central authorities: the latter have a stake in this type of resistance, since it helps keep track of transgressors of their policies and thus constitutes a means of reaffirming their power over local cadres. As one protest leader stressed in a highly realistic tone, "What I am struggling against also undermines Party rule." Another activist insisted that, "So long as China 's president wished to stay in power, he would need people like him to help control wayward local officials" (p. 90). The Centre publishes laws and policies but has no interest in seeing them systematically implemented, partly because it needs to juggle the interests of local governments with which its own are linked, but also because proper implementation would mean political reforms that would weaken the Party's might. Now "rightful resistance" seems like a solution to this basic contradiction: by seeking intervention from higher levels of administration, this form of resistance helps the Centre respond to conflicts through ad hoc solutions that expand its capacity to manage contradictions while withholding political reform. Of course, as the authors point out, this method does not always succeed, hence the radicalisation of modes of action reflecting the "affirmation of a right to resist rather than to denounce," as the protesters increasingly see themselves as enforcers of law rather than as informants letting the Centre know that its policies are being violated (p. 68). While this radicalisation may indicate a drop in confidence in the Centre's ability to implement its policies and keep its officials in check, it actually leads to increasing efforts to help the Centre and does not, therefore, reflect any change in the attribution of responsibility. The Party thus gains new "martyrs" even less inclined to question a regime that is adept at coopting them. In fact, this resistance is relatively effective: it induces a better implementation of public policies, helps set limits on local officials' arbitrariness, and fights corruption. Not only does it help improve application of laws, it also compels the regime to better adapt itself to cope with social and economic changes without embarking on any basic alteration in power relations. In this regard, the authors show that such resistance is not merely reactive but also proactive. All these elements lead one to think that this form of resistance is doomed to remain a perpetual mobilisation that cannot transform itself into a fight for institutional guarantees of rights because of its basic role supporting the functioning of the regime. Why go in for political reforms if the systemic failures are compensated by the mobilisation of the people? It would thus appear that this form of resistance is an integral part of the regime's dynamic stability, though that does not rule out the possibility of the balance being upset some day.

7 Clearly, the book opens debate that can be expected continue indefinitely in the scientific community, especially as it calls upon other researchers to pursue field work and theoretical reflection. To the many avenues for future research suggested by the authors, two more could be added. The first would be to develop a historical perspective comparing "rightful resistance" to the tactic used by the Red Guards during the Cultural Revolution of "waving the red flag to fight the red flag " (qu hongqi 
da hongqi) and thereby better understanding its scope. This would require reworking the discourse of the powerful against the powerless and the exploiting of divisions within the elite, more specifically drawing on factional disputes during the Cultural Revolution. Contrary to what the authors seem to be saying, the Chinese have always been aware of divisions among those in power and of the need to find patrons among the mighty in order to safeguard their personal interests ${ }^{3}$ or to advance the values they believe in ${ }^{4} \mathrm{On}$ the other hand, notions of rights and of reciprocity were not absent in the Maoist era (it was always stated that cadres should serve the people), nor indeed were notions of participation (within the work unit as in the public place through the use of dazibao), all of which is highlighted by the fact that some protesters interviewed by O'Brien and Li specifically refer to such Maoist precepts. Of course, "rightful resistance" innovates: to the extent that it demands strict application of laws, it testifies to the emergence of law as the legitimate and prevailing norm in relations between state and society. A comparative historical study would thus facilitate a better understanding of the evolution in the repertory of collective action and of motivations behind some elites' support for such resistance. To what extent does "rightful resistance," which is closely linked to the expanding juridicisation of the relations between the state and Chinese citizens, not reflect a paradoxical advance of apoliticism? It would seem that similar resistance strategies that earlier sought to redefine power relations and destabilized the regime tend now to preserve it and help strengthen it. If such is indeed the case, China may be proceeding in a direction diametrically opposed to that analysed by Charles Tilly in Europe, where modernisation brought about a politicisation of the repertory of protests, thus leading to the development of citizenship.

8 Another route of enquiry that could be pursued would be to pay more attention to the social and political environment in which such resistance is growing now. This environment is uniquely accounted for from a structural point of view, and the authors show clearly how much the paradigm of "rightful resistance" owes to the state structure and the nature of the Chinese regime. Meanwhile, circumstantial changes could have major repercussions on the structure of political opportunities. For instance, to what extent have the change of leadership in 2002 and the adoption of new populist discourses favouring "underprivileged categories" - peasants being the chief among them - influenced the radicalisation of demands? How much bearing does public opinion in its larger sense have on the claims, and does it perhaps contribute to maximising their impact? This would require focusing on the observations of experts, public intellectuals ${ }^{5}$, and the media. O'Brien and Li mention media support for protesters: what arguments do the media develop to lend direction and legitimacy to protest actions? What reasons are adduced for the lack of application of Central laws and policies, and how do they differ from the reasons the protesters come up with? It seems that that an extensive public policy framework favouring the countryside was adopted in 2004 as a result of support for peasants' resistance from experts and public opinion.

9 This book can be highly recommended as a major contribution to political science that sheds new light on the relations between state and society in China and raises key questions regarding the evolution and mode of functioning of the regime. In addition, the book is a highly agreeable read, not only because it is organized, as the authors themselves describe it, "like an episode of collective action," or like a novel with 
suspense, plot development, and denouement (which however remains open), but also because of the lively interaction between fieldwork and theory.

\section{NOTES}

1. he protesters refer as much to rights clearly set out in law as to the more informal and thus more debatable - rights recognized in Central policies or deduced from leaders' discourses.

2. The authors show that this form of resistance, which can appear whenever there is a gap between what is promised by the authorities and what is effectively guaranteed, is characterised by either the social group that undertakes it or by the political system in which it takes place. Going by the examples cited by the authors, it can occur in countries where there is no rule of law and/or be undertaken by marginalized groups or those lacking any power or special status.

3. See Xu Youyu, Xingxingsese de zaofan (All sorts of rebellions), Hong Kong : Zhongwen daxue chubanshe, 1999.

4. This was in fact the case of the Shengwulian, an association of Red Guards in Hunan, whose activities have been described in Révo. Cul. dans la Chine pop (Cul Rev in Pop China) Anthologie de la presse des gardes rouges. Prepared by Hector Mandarès, Gracchus Wang et al. Paris , Union générale d'éditions, 1974.

5. Many fiery commentaries denouncing the peasants' condition were published during the decade studied by the authors. The following three drew much attention: Cao Jingqing, Huanghe bian de Zhongguo: Yi ge xuezhe dui xiangcun shehui de guancha yu sikao ( China along the Yellow River : reflections on rural society), Shanghai, Shanghai wenyi chubanshe, 2000; Li Changping, Wo xiang zongli shuo shihua (Telling the premier the truth), Beijing , Guangming Ribao chubanshe, 2002; Chen Guidi, Wu Chuntao, Zhonguo nongmin diaocha(Chinese peasantry: a survey), Beijing, Wenxue chubanshe, 2004. Many fiery commentaries denouncing the peasants' condition were published during the decade studied by the authors. The following three drew much attention: Cao Jingqing, Huanghe bian de Zhongguo: Yi ge xuezhe dui xiangcun shehui de guancha yu sikao ( China along the Yellow River : reflections on rural society), Shanghai , Shanghai wenyi chubanshe, 2000; Li Changping, Wo xiang zongli shuo shihua (Telling the premier the truth), Beijing , Guangming Ribao chubanshe, 2002; Chen Guidi, Wu Chuntao, Zhonguo nongmin diaocha(Chinese peasantry: a survey), Beijing, Wenxue chubanshe, 2004. 